\title{
Reading "KERESIJO WEKE” and other Designations of Tripods on Mycenaean Tablets
}

\author{
Ioannis K. Kenanidis ${ }^{1}$ \\ ${ }^{1}$ Primary Education Directorate of Kavala, Kavala, Greece \\ Correspondence: Ioannis K. Kenanidis, Primary Education Directorate of Kavala, Ethnikis Antistaseos 20, 65110 \\ Kavala, Greece.
}

Received: March 4, 2019; Accepted: March 17, 2019; Published: March 26, 2019

\begin{abstract}
This work examines the designations for tripods on the tablets PY Ta 641-1952 and PY Ta 709+712, which have been puzzling and misinterpreted since their discovery until now. These tablets are examined in connection to each other, using a detailed etymological analysis, the common sense of accountants, and close observation of the sketches on the tablets. It is explained why the term "keresijo" has nothing to do with Crete and why "ai-ke-u" or "ai 2 -ke-u" as traditionally read on the tablets mentioned is not a personal name. The result is a translation given for the texts related to vessels and especially tripod cauldrons on these tablets.
\end{abstract}

Keywords: Linear B tablets, Mycenaean Greek, Crete, Cretan, etymology, Proto-Indo-European, Pylos, tripod cauldrons

\section{Introduction}

\subsection{The Tablets of Tripods}

Pylos tablet Ta 641-1952 is probably the most famous tablet of Linear B. In one of his lectures, professor John Chadwick said that "Greeks should be grateful to this tiny piece of charred clay, because it proved that the Linear B (LB) language is Greek". Proof for the correctness of a decipherment is usually offered by bilingual documents; for LB there is no bilingual document, but this tablet is rich in "ideograms" which can confirm that the reading of the syllabograms is correct. The term "ideograms" can be misleading: those signs do not convey any abstract ideas, they are only sketches of the things counted and recorded on the accounting documents (clay tablets). So, the term "sketches" will be preferred in this work.

Personally speaking, this tablet, PY 641-1952, is the one that introduced me to Linear B since I found a photograph of this tablet (identical to fig. 2) in the official school book of history when I was a 12-year-old pupil.

Another picture of the tablet is presented in fig. 1 (which clearly shows M. Ventris' knowledge about it and the state of research at that time, 1952, which essentially remains at the same level until now) and, together with the other relevant tablet, in fig. 3 (a high resolution color photo, that can be seen by following the link given).

The caption in the history book said that "after the syllabic signs for a tripod, "ti-ri-po-de", there is a drawing of a tripod, and so on".

At that time I thought that everything about Linear B is known and that all discovered tablets are deciphered, although the caption said that their (the tablets') reading is difficult. At least this tablet ought to be perfectly read; I could not imagine, as a child, that there are serious problems with the reading even of this famous tablet which so much helped the specialists to decipher it.

It will be clearly shown below that the direction of the research has been wrong in thinking that the tablets speak of provenance or people who had to do with the tripods; instead, the tablets are concerned with the condition and usability of the tripods.

\subsection{A detailed examination of previous readings and interpretations of the texts related to tripods}

The PY 641-1952 tablet, according to the traditional system of transliteration, is transcribed as:

- 1st line: "tiripode $a_{3}$ keu keresijo weke CAULDRON 2 tiripo eme pode owowe CAULDRON 1 tiripo keresijo weke apu kekaumen(o) kerea."; 
- 2nd line: "qeto JAR 3 dipa mezoe qetorowe VESSEL 1 dipae mezoe tiriowee VESSEL 2 dipa mewijo qetorowe VESSEL 1";

- 3rd line: "dipa mewijo tirijowe VESSEL 1 dipa mewijo anowe VESSEL 1".

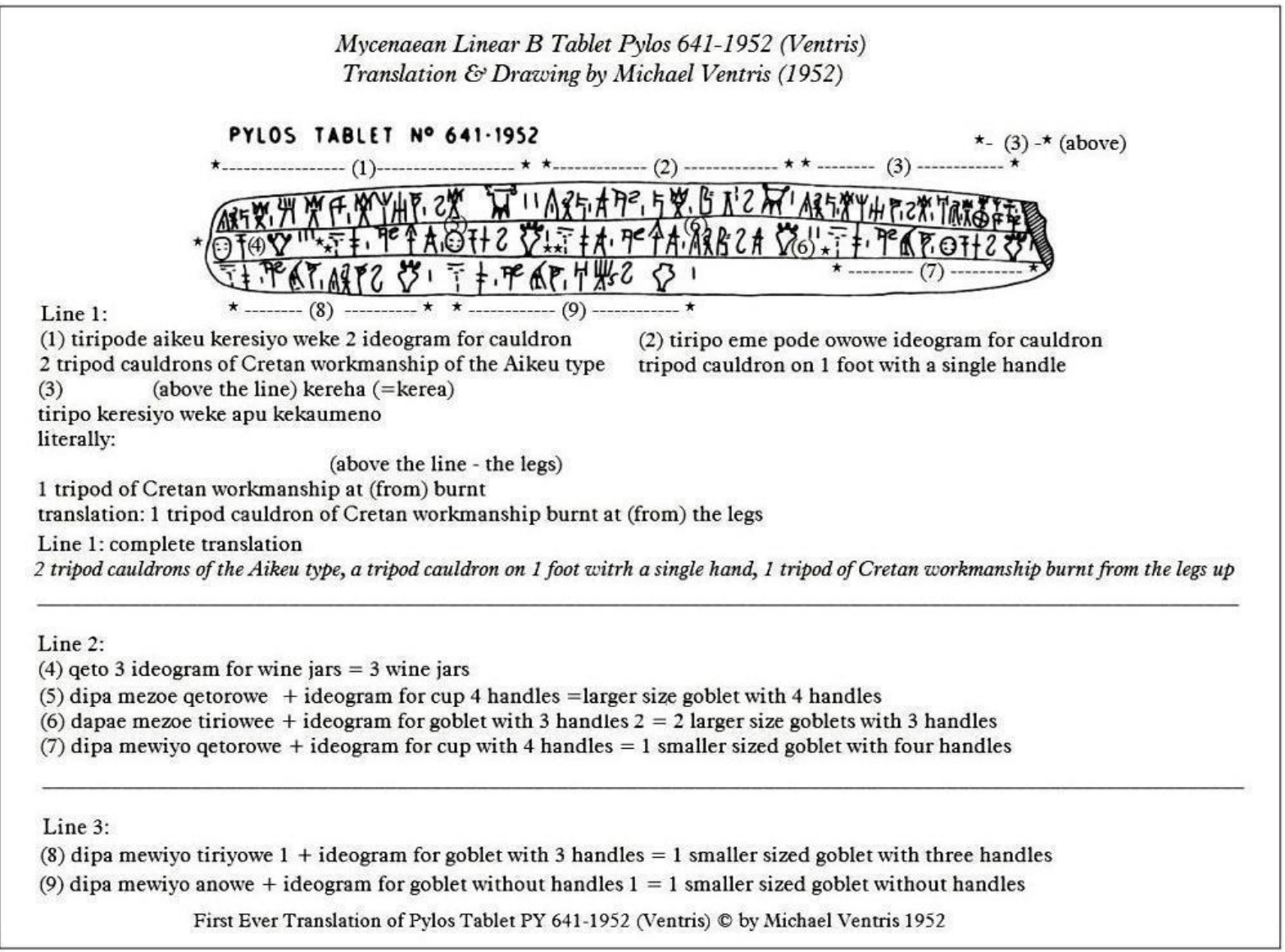

Figure 1. Drawing and translation of Pylos tablet TA 641-1952 by Michael Ventris (1952). From https://www.academia.edu/23643380/Archaeology_and_Science_Vol._10_2014_An_Archaeologists_Translatio n_of_Pylos_Tablet_641-1952._pp._133-161

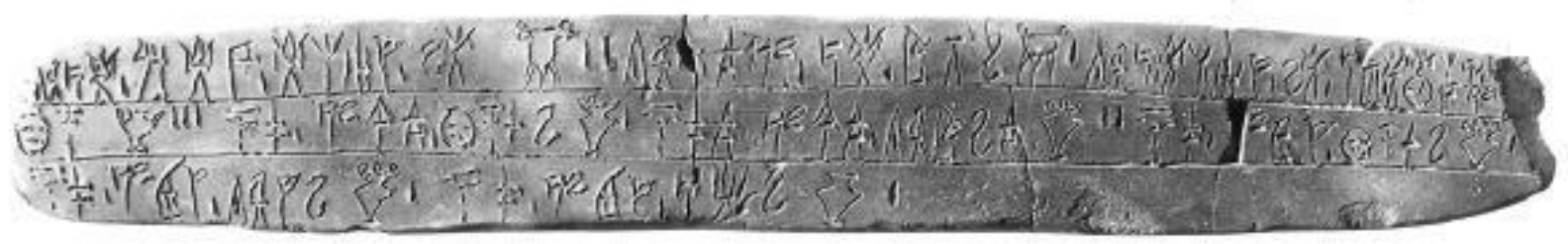

Figure 2. Photograph of Pylos tablet TA 641-1952. From http://www.classics.cam.ac.uk/Research/projects/mycep/decipherment

There are some problems with the translations M. Ventris gave to the various vessels:

- "dipa" cannot be a "goblet", because goblet is "1. A drinking glass with a base and stem. 2. A bowl-shaped drinking vessel; especially the Eucharistic cup" (WordWeb dictionary), while the "ideograms" make it clear that "dipa" is not a drinking vessel, but one used for storage of liquid. It is convenient to translate simply "vessel". So here I agree with (Chantraine, 1968) sub voce (s.v.) " $\delta \varepsilon \dot{\pi} \alpha \varsigma$ ", including the opinion that the word is probably a loan-word from Luwian, and I suggest that it was some popular false connection to Greek root dap- "to spend, consume" and "dais" (mealtime) that made the meaning change 
to "wine drinking vessel".

- "qeto" is supposed to be the vessel called pithos in Classic Greek, an opinion shared by (Chantraine, 1968: s.v. " $\pi i \theta o \varsigma ")$, but after observing the sketch ("ideogram") for the "qeto" and the shape of the early "kuathos", I am convinced that "qeto" was the early form of "kuathos" and not "pithos". The classical "kuathos" was a vessel with one long handle, used for serving wine, but the earlier the era, the more similar to the sketch on the tablet was the "kuathos": shorter and broader than the classic "kuathos", it had two handles, and sometimes a spout for pouring. "Pithos" was the largest vessel used by the ancient Greeks for storing (olive oil and other goods), analogous to a modern barrel, and it was never similar to the sketch of "qeto" on the tablet, which shows it even smaller than the "dipa" (the size of the vessel is inferred by the size and position of the "ears", i.e. its handles drawn in the sketch; the "pithos" has the smallest handles in proportion to its body, while "qeto" has bigger handles than the "dipa").

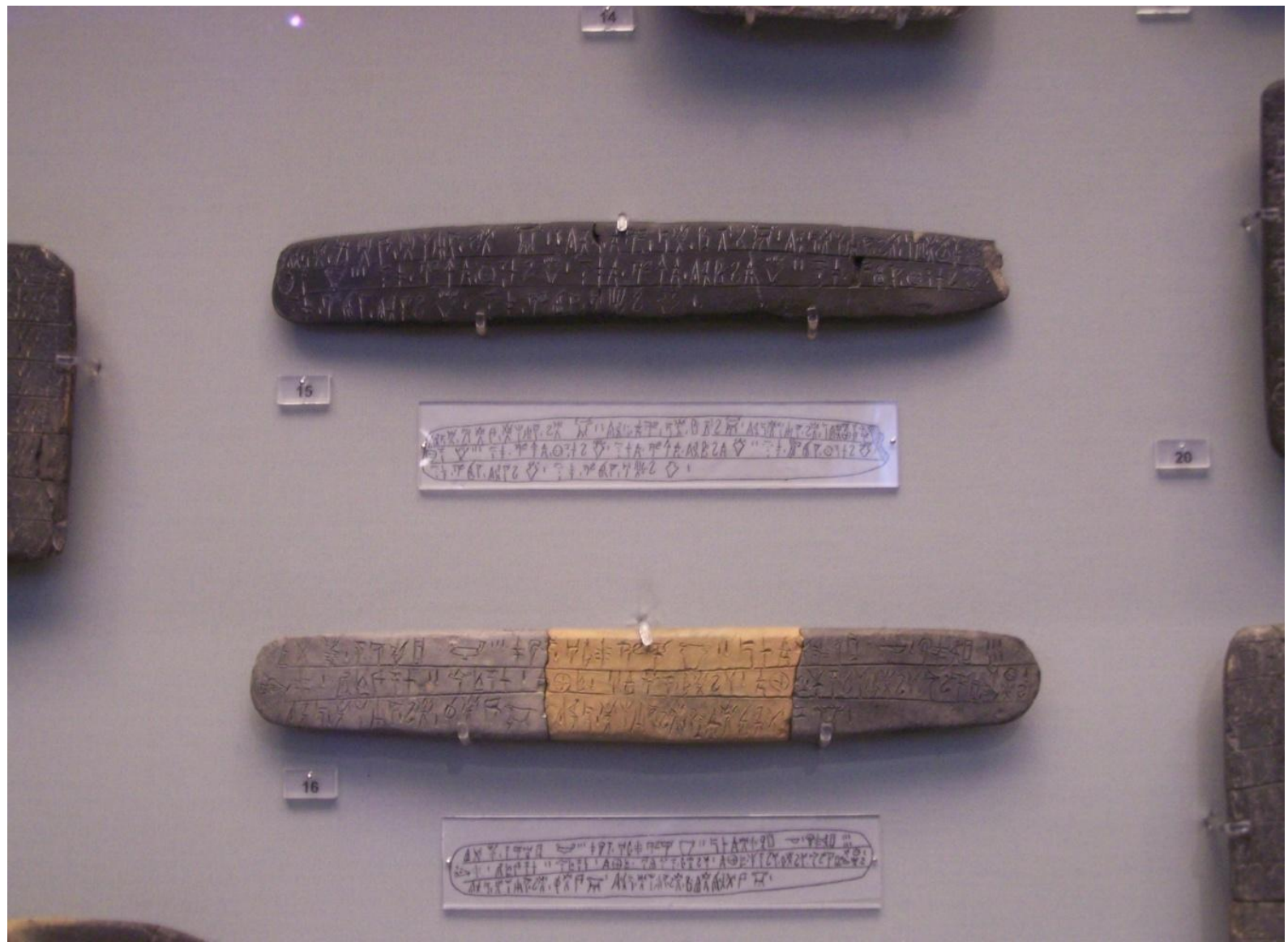

Figure 3. High resolution photograph of tablets PY Ta 641-1952 (above) and PY Ta 709+712 (below). From https://resgerendae.files.wordpress.com/2013/04/106_3357.jpg

"Cauldron" is a good translation for "tripod-". It was used for boiling. Having three legs ensured that it stood steady even if a leg would be a little shorter or longer than the others, and in between the three legs of the tripod a fire would burn for boiling water or cooking the food in it.

The main problems in reading this tablet, however, are not the names of the vessels, but the words "a $\mathrm{a}_{3} \mathrm{keu",}$ "keresijo" and "weke".

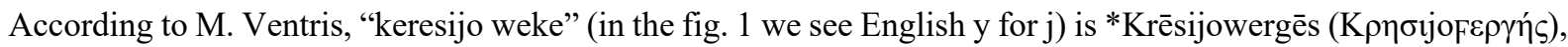
meaning *"of Cretan workmanship", and "a $a_{3} k e u$ " is "of aikeu type", that is "an unknown designation of the tripods".

However, already in "Documents" (Ventris \& Chadwick, 1953) there is another tentative interpretation too:

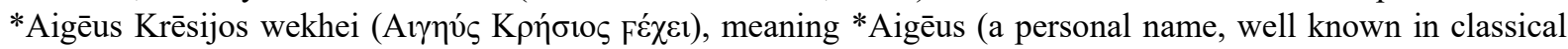

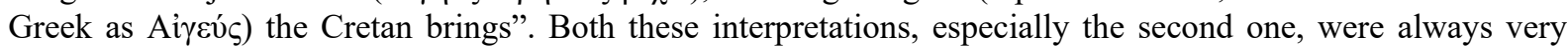


dubious, and it is now explained why they must be simply unacceptable. There is no other indication on any other LB tablet of a person who brought an object; and there is no other "we-ke" except in the phrase "keresijo weke"; even if on the PY Ta 641 it were *Aigēus Krēsijos, (supposing Krēsijos=a Cretan man), then on the same tablet PY Ta 641 and on PY Ta 709+712 "keresijo" is mentioned another three times without a connection to anything that might have been a man's name. So, by common sense, the interpretation "Aigēus Krēsijos" is totally impossible. Even if we look closer to the supposed verb "wekhei" ("weg'hej" in traditional transcription of IndoEuropean), that would be necessarily from the PIE root "weg' $h$ " (Note 1), a well-known root meaning "a vehicle; to carry with a vehicle" (the very word "vehicle" comes from this root); but while there are known Greek words

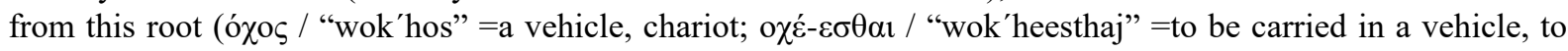
ride), a verb form *"wekhei" has never been attested in any form of the Greek language; that *"wekhei" would anyway mean "he carries with a vehicle", and even this meaning would be absurd in the context of the tablet: *"two cauldrons are carried with a vehicle by Aigēus the Cretan"(!).

A newer interpretation was given by R. Roberts, to which R.V. Janke agrees with enthusiasm: "Aigeus is working on two tripods of the Cretan style" (Janke, 2014, p. 19; fig. 7). This means that "weke" is read as "werg'ej", supposed to mean "his is working", but there is no such verb in the whole Greek language; the verb from the root "werg" in the meaning "he is working" is found many times in LB as "woze" (read "worzej", from *worg'jej), see DMic. (Diccionario Micénico) and Documents (Ventris \& Chadwick, 1953), therefore the verb was "worzej" and not *werg'ej in Mycenaean Greek.

Furthermore, this tablet is a list of things; it cannot contain any verbs, because it is not a report of who is doing what, it simply records objects and in how good condition they are preserved.

Even if we suppose that "weke" makes sense in this sentence as "(Aigeus) is working (on two tripods)", then what is the sense in the other three sentences where "weke" occurs? Who "is working on tripods of the Cretan style" in the other three sentences? How would R. Roberts or R. V. Janke parse and interpret all of those 4 sentences on those two tablets?

Moreover, the phrase "tiripode a $a_{3}$ keu keresijo weke" cannot be taken as "Aigeus is working on two tripods of the Cretan style", because if that were intended, the text, by means of the words' order, would join the cauldrons ("tiripode") to "keresijo" and "Aigeus" to "weke", e.g. *"tiripode keresijo a $a_{3} k e u$ weke" or *“a ${ }_{3}$ keu weke tiripode keresijo"; or even *"a 3 keu tiripode keresijo weke", but it would never be "tiripode a $a_{3} k e u$ keresijo weke", as the tablet really says.

The conclusion is that there is no way to make sense of the text if we ever take "a $a_{3} k e u$ " as a name or "keresijo" as "Cretan".

Note also that beyond "keresijo weke", there is no LB tablet that mentions the provenance of a commodity or artefact at all.

It is obvious in the whole tablet that the scribe tried her (Note 2) best to give a very detailed description of the objects: how many handles they have, what is their relative size, a tripod has a handle on one of its legs, another tripod is a little burnt at its legs; in other words the scribe wanted to give a detailed description of the form and the condition of objects kept in (her) storeroom. It is obvious that (she) had to safeguard the objects and give a clear account at any time a superior would ask e.g. "why is that tripod damaged?"; "where did you find this "dipas'?"; "the jar we lost, is it maybe here?"; "have you kept all the jars you received in good condition?" and so on. This tablet is what we call today a "Certificate of (Delivery and) Acceptance", that is a document recording objects that somebody receives, and is entrusted with, from another person. In such a document it is important to describe the objects in detail so they can be identified later without ambiguity, and also it is important to record in how good or bad condition the objects are. However, to record if the tripods are of Cretan workmanship is quite irrelevant, unless if this can be recognized in their appearance. But could a tripod be recognized by its appearance as "Cretan"? Of all that I can understand or imagine, there was no characteristic of the tripods, or of the "ideograms" used for them on the tablets, that could make them recognizable as "Cretan ones". After all, what can make us believe that the word "keresijo" meant "Cretan"? There is not even a slight indication that Crete was known by that name ("Krêtā") at the time that the tablets were written. Wikipedia has spread a wrong idea that the name "Krētā" is very old and even existed in Mycenaean Greek, by saying that the word "ke-re-te (*Krētes)" is attested on PY An 128 tablet, but this is bluntly wrong; the tablet is presented in fig. 4 (from Ruijgh, 1962), so you can see it is not "ke-re-te", but a man's personal name "ke-re-te-u", probably Krēthēws (Ventris \& Chadwick 1953), a name well

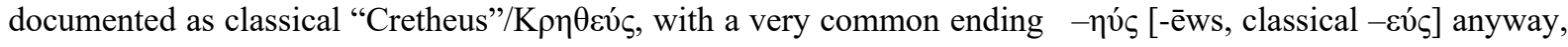
and it has nothing to do with the classical word "Krètes" which is in plural, while the personal name on the tablet 
is clearly in singular, being the subject of the verbs "ekhej" and "ōnato" ( $\varepsilon \chi \varepsilon 1, \omega ́ v \alpha \tau o$, meaning "he holds, he has been benefited (i.e. received)" (Note 3).

\section{PY Ea 800 , Doc. Iro (ms 43) ke-re-te-u / e-ke o-na-to pa-ro mo-ro-qo-ro po-me-ne FRUM. 2}

Figure 4. Text from tablet PY An 128.

Palaeolexicon too (http://www.palaeolexicon.com/ShowWord.aspx?Id=17101) records "ke-re-te-u" as a personal name, and no word *"ke-re-te".

That whole tablet reads "Krēthēws ekhej ōnato parō mologrōn pojmenej WHEAT MEASURES: 2", which,

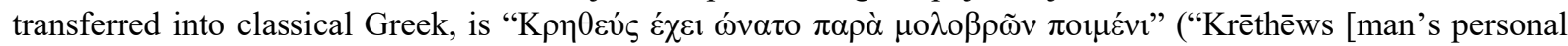
name] holds, has received, 2 measures of wheat from the herdsman of the pigs"). ' $\Omega v \alpha \tau$ (onato) is simple past

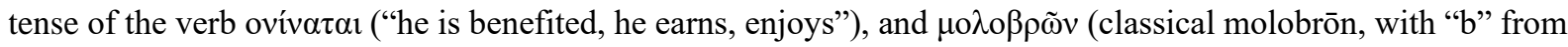
older velar "g") is definitely not a personal name, but a description of profession together with $\pi$ ou $\mu \varepsilon^{v}$ (classical

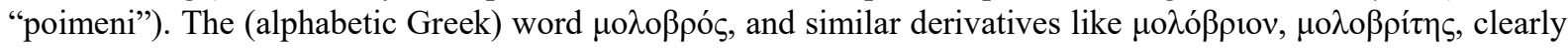
mean a kind of pig, which has constantly its snout on the ground greedily searching and devouring all plants and creeping creatures, so $\mu о \lambda о \beta \rho \tilde{\nu} v \pi \circ \mu \eta \dot{v} v$ =the herdsman of (that type of) pigs (Chantraine, 1968, p. 709).

Also, an alphabetic form "крฑ́бıь" (krēsijos) has scarcely been attested in the Greek language, and that only in highly elaborate poetic language (to fit the prosody) and as part of three (geographical or mythological) names;

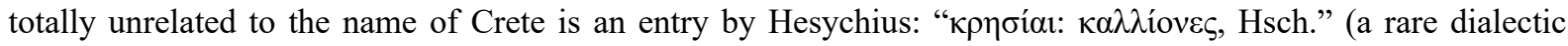
variant of $\kappa \rho \varepsilon i ́ \sigma \sigma o v \varepsilon \varsigma$, defined by Hesychius himself as "more beautiful girls/ladies"), and equally unrelated is

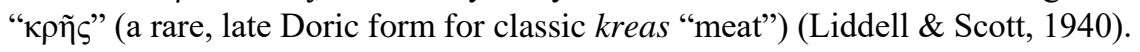

The etymology of "Crete" is obscure; the island of Crete was internationally known as "kaptara" and similarly, which, according to Kenanidis (1992; 2011), came from the Sumerian autonym \{cwepeto(r)\}, also recorded as the Egyptian name "K-F-Tj-W", which, according to O. Dickinson (1994, p. 241-244) "strongly suggests a similar Minoan name for the island". All those variants of the ancient name are too remote to Krête (attested for the first time in Homer's Odyssey, $8^{\text {th }}$ century BC) to make us believe that the word Krētāa (hence Krēsijos) was known when the LB tablets were written, and we have seen that a word Kresijos supposedly meaning "Cretan" cannot fit the context in the two tablets where it appears. To make "keresijo" fit, it is assumed, furthermore, by the first

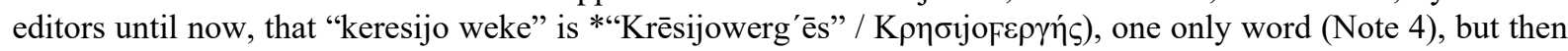
it would be odd that it was always written as two separate words: "keresijo weke", separated by a word-dividing line, all the four times that it was written, by the same hand, on two tablets (hand PY 2, on tablets PY Ta 641, PY Ta 709+712); and we cannot assume that the scribe habitually divided long words, because the same scribe wrote words of more than 6 signs without word division ( "po-ro-e-ke-ti-ri-ja", "o-pi-ke-wi-ri-je-u"), see Ruijgh (1962) and figures $3,5,6$.

To the two occurrences of "keresijo weke" on the tablet PY Ta 641, we should add the two occurrences on the tablet PY Ta 709+712 as recorded in the transliteration of (Ruijgh 1962) and (Chadwick 1955) presented here in fig. 5 and 6.

\section{Method}

\subsection{The Role of Transliteration, Mycenaean Phonology and "ə" ("schwa")}

The traditional transliteration of Linear B (henceforth LB) is really praiseworthy because it reflects a sensible understanding of Mycenaean phonology, that understanding contained, however, some misconceptions which have not been cleared, but rather increased, since the time of LB decipherment.

Clues to understand Mycenaean phonology better are the pronunciation of Greek in later stages and even in Modern Greek dialects; the knowledge of other ancient Indo-European (IE) languages; and, last but not least, the knowledge of the Proto-Linear (PL) script and the dialects of the Sumerian language. 


\section{PY Ta $709+7$ I2 (PT II et AJA 62 (I958), p. I82), Doc. 237 (ms 2)}

I. pi-je-ra $a_{3}$ to-qi-de-ja SARTAGO 3 pa-ko-to a-pe-te-me-ne ALVEUS 2 po-ro-e-ke-te-ri-ja cOCHLEAR I ko-te-ri-ja 6 2. $s i_{2}$-te I pu-ra-u-to-ro 2 qa-ra-to-ro I e-ka-ra a-pi-qo-to pe-de-we-sa I e-ka-ra i-to-we-sa pe-de-we-sa so-we-ne-ja $s i_{2}$-de-we-'sa-qe $\mathrm{I}^{\prime}$

3. $t i-r i$-po ke-re-si-jo we-ke *34-ke-u TRIPUS I ti-ri-po ke-re-si-jo we-ke o-pi-ke-wi-ri-je-u TRIPUS I

\section{PY Ta 64I, Doc. 236 (ms 2)}

I. $t i-r i$-po-de // $a_{3}-k e-u$ ke-re-si-jo we-ke TRIPUS ${ }^{\mathrm{b}} 2$ ti-ri-po $e$-me po-de o-wo-we TRIPUS I ti-ri-po ke-re-si-jo we-ke $a-p u k e-/ k a-u-m e-n o$ 'ke-re-a $a_{2}$ TRIPUS ['

2. qe-to URCEUS 3 di-pa me-zo-e qe-to-ro-we POCULUM ${ }^{4}$ I di-pa-e me-zo-e ti-ri-o-we-e POCULUM ${ }^{3} 2$ di-pa me-wi-jo qe-to-ro-we POCULUM ${ }^{4}$ I

3. $d i$-pa me-wi-jo ti-ri-jo-we POCULUM ${ }^{3}$ I di-pa me-wi-jo $a-n o-w e$ POCULUM ${ }^{0}$ I

1. -me-nọ Doc. | 'ke-re-a 2 nọ-[pe-re' tripus r] Doc.| 2. me-zo- $\{\mathrm{e}\}$ Doc.

Figure 5. Transliteration of the two tablets which contain the phrase "keresijo weke", from Ruijgh (1962).

Ta709.1

.2

.3

$p i-j e-r a_{3}$ to-qi-de-ja ${ }_{200} 3$ pa-ko-to a-pe-te-me-ne $\star 2142$ po-ro-e-ke-te-ri-ja IMPLEMENT 1 ko-te-ri-ja 6.

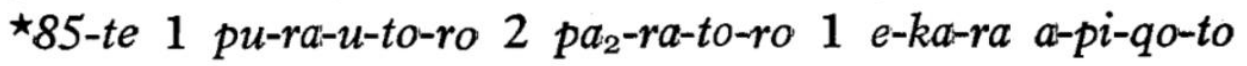
pe-de-we-sa 1 e-ka-ra i-to-we-sa pe-de-we-sa so-we-ne-ja $\star 85-d e-w e-s a-q e 1$.

ti-ri-po ke-re-si-jo we-ke $a i_{2}-k e-u$ TRIPOD 1 ti-ri-po ke-resi-jo we-ke o-pi-ke-wi-ri-je-u TRIPOD 1. Tablet completed by Lang, $A \mathcal{F A} 62.182$.

Figure 6. Transliteration of the tablet PY Ta 709+712 in Chadwick (1955).

Proto-Indo-European (PIE) studies have gone progressively on a wrong way because of the trend to see "laryngeal" sounds everywhere and so ignore the fact that PIE had also some central vowels: a short "a" and a long "a" as well, not only front ("e") and back ("o") vowels. The "Schwa Indogermanicum" is nothing else but the PIE short "a", which was "closer" than the PIE long "a", in other words, the PIE short "a" was a real/a/ (a mid-central unrounded 
vowel). As ancient Greek was the most conservative recorded language descending from PIE, the original Greek short "a" was /a/ as in PIE; although that was later modified, we can be sure that the "a" in the Mycenaean diphthong "ai" was exactly /ə/, for the following reasons:

- it descended from the PIE (and original Greek) short "a", that is /a/;

- it was rendered by the Sumerian signs for $/ \gamma /$, which was the closest available means to write $/ \partial /$, and marginally, in some Sumerian dialects and sociolects, /// was pronounced instead of $/ \mathrm{\gamma} /$;

- Mycenaean "a" in "ai" (that is /oj/) was not the same as "a" alone (without a -j or -w coda), since different syllabograms were used for "a" and different ones for "ai"; this means that the $-\mathrm{j}$ (probably also the $-\mathrm{w}$ ) kept the "a" higher (closer vowel) than the mere "a". This is why the Mycenaean "ai" was rendered with the signs for Sumerian $/ \gamma /$ (e.g. LB 43). In some cases, however, the same sign stands for both "a" and "aj", e.g. LB sign "ja" is also used for "jaj" too, either because the scribe had forgotten the rare sign for "ja" or, more likely, because in "jaj" the "a" was not made higher; this proximity, but not identity of the two vowels shows that they were similar, differing only in height (/ä/ versus /ə/).

- Mycenaean "a" was not a back vowel, as we shall see in this work that long Mycenaean "a" was near to long "e" (a tendency generalized later in the Ionian or "eastern Greek" dialects: Appendix B).

So, Mycenaean "a" in "ai" (in fact/oj/) was /a/, while the independent short "a" was quite opener and long "a" was also fronted. The important for the present study is " $a$ " in Mycenaean "ai" /aj/ because that is crucial in reading the tripods' tablets.

The Sumerian language has been already mentioned; it would be absurd if the whole Sumerian civilization (including language and the art of writing) had been always confined to southern Mesopotamia without affecting the writing systems of Cyprus and the Aegean which are clearly related to each other, when we know of the adventurous character of the Sumerian nation, the fact that Sumerians are known as the first inventors of writing, the necessity for ancient nations to travel, trade and colonize to distant lands, and the main writing material being the same unbaked clay for Mesopotamian Sumerians and the Minoan writing systems.

It has been explained in detail (Kenanidis, 1992; 2011) that the whole Minoan (including Cypro-Minoan) civilization was due to Sumerians who settled especially on Crete since the beginning of the $3^{\text {rd }}$ millennium BC; and the writing system used by those Sumerian settlers evolved from pictography to Proto-Linear (PL).

For those familiar with LB, Linear A (LA), Cretan Hieroghlyphic (CH) and the Cypro-Minoan (Linear Cypriot, LC) script, it is easy to understand what Proto-Linear was: the syllabic script that all other Aegean and Cypriot syllabic scripts originated from; rather, it is more accurate to say that LB and LA were only applications of PL for writing languages other than Sumerian, while PL itself was devised and used for Sumerian by Sumerians.

Although the Linear B tablets were written in pure Greek (Achaean) language, the study of Cretan Proto-Linear (CP, conveying the Cretan Sumerian dialect) will prove to be indispensable for the complete understanding of Linear B and for solving problems with the reading of the LB tablets; it is exactly because of hitherto ignoring or not applying the knowledge of Proto-Linear that research has remained essentially stagnant since the time of the first decipherment of LB (1952), because it is only the study of Proto-Linear that sheds light on the exact phonetic use of LB signs and on the hitherto unknown phonetic value of about 1/10 of the LB syllabograms inventory.

This is why the tablets and words on them will here be transcribed not only in the traditional system used for LB, but also in the system used for transliterating the Proto-Linear, which uses "c" for emphatic palatals and "q" for non-emphatic but aspirated velars ("k" and "g" reserved for non-emphatic palatal aspirate and emphatic nonaspirate velar respectively, these two not attested in Cretan PL). In contrast to (Kenanidis, 2011), where "1" (the dotless i) is used for a Sumerian vowel "similar to Turkic /u/", that vowel was in fact $/ \gamma /$ in most dialects and /a/ in others (Kenanidis \& Papakitsos, 2018), so "ə" will be used for transliterating the Proto-Linear too, although "ə" had not exactly the same use when writing the Mycenaean (Achaean) Greek language.

To distinguish between systems of transliteration, the traditional transliteration of Linear B will be in quotation marks ("'), while curly brackets \{\} are used for the Linear B signs treated as signs of the Cretan Proto-Linear (CP).

\subsection{Texts about Tripods on the two "KERESIJO WEKE" Tablets}

According to the mentioned system for transliterating the Proto-Linear script (Kenanidis \& Papakitsos, 2018), the lines about cauldrons on those two tablets read:

- PY Ta 709+712: \{tilipo celesijo wece niceu CAULDRON 1 tilipo celesijo wece opicewilijeu CAULDRON 1$\}$ 
- PY Ta 641: \{tilipode əceu celesijo wece CAULDRON 2 tilipo eme pode owowe CAULDRON 1 tilipo celesijo wece abu cecaumen(o) celeha\} (slight breakage on the end of tablet, so "ideogram" missing; "celeha" is underlined only to indicate that it was written over another word, because there was no other room for it on the line of the tablet).

\subsection{Reading the Crucial Term "keresijo weke"}

The whole context of these two tablets shows that the scribe was concerned to describe how suitable for use the cauldrons were: this is anyway the most important concern for any document recording things received and entrusted for a storehouse. This makes the words "keresijo weke" very easy to recognize as the Greek words

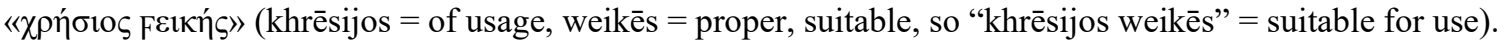

These two words, "keresijo weke" are the key for understanding the whole of the texts referring to tripods on the two tablets discussed, after it has been explained that "keresijo weke" = suitable for use; it is surprising that FEוkńs

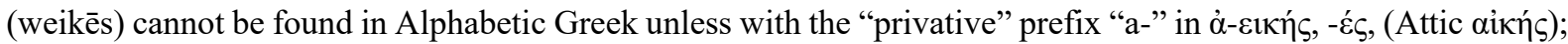
this prefix "a-" was added to any word in Greek (and in Sanskrit exactly in the same way) to form a word with the opposite meaning, so the meanings of FEוkń (weikēs /wejce:s/) are perfectly known as exactly the opposite of $\dot{\alpha}-$

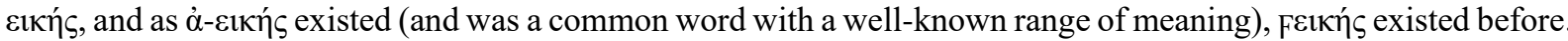
It was formed by the PIE root w(e)jk' meaning "to be matching; suitable; proper; just; agreeable; fair; resembling; seeming true or natural; expected"; today the root is known mostly for the meaning of "resemblance" (as in the derivative "eikōn" hence English "icon"), however the original meaning of the root was "well matching"; the root has given a great many words in Greek. "Khrēsijos" is the genitive of "khrēsis" ( $\chi \rho \tilde{\eta} \sigma 1 \varsigma$, "use, usage") a wellknown word; the genitive goes before the modified word as always in Mycenaean and as usually in old Greek prose.

\subsection{The Exact Meaning of the Term "apu kekaumeno"}

As to $\{a b u$ cecaumeno $\}=$ "apu kekaumeno", corresponding to classic $\alpha \pi \circ \kappa \varepsilon \kappa \alpha v \mu \varepsilon ́ v o \zeta$ (apokekaumenos), the dictionary (http://perseus.uchicago.edu/cgi-bin/philologic/getobject.pl?c.7:4:137.LSJ) gives "burn off", which means, in all cases, to cauterize or burn the extremities of things, but not the whole things (Appendix A).

That is why I translate "burnt around". The legs of a cauldron were made of bronze; they could not really be burnt, unless on the surface, and that "burning" was simply the discoloring that fire causes on metals (not so much by soot, rather by intense heating). Such "burning" on the cauldron's bronze legs, although it makes the legs look already used and somewhat ugly, does not make the cauldron less usable. That is why the tablet describes the

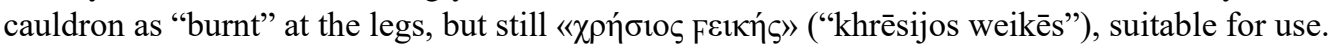

The fact that the "apu" (classical "apo") is written as a separate word, and not as a component in *"apukekaumeno", indicates that it was pronounced and understood as a separate word (a usage common in the earlier stages of Greek, Sanskrit and other IE languages), and so the original meaning of "apo" ("away", i.e., on the edges, on the outer, on the surface only) is better preserved than when used as a preposition component of a bigger word.

\subsection{Etymological Analysis of \{aceu\} and \{niceu\}; the Hitherto Misinterpreted Sign "ni"}

The most elusive question about these cauldron texts, however, is about the words \{niceu\} and \{aceu\}. What I transcribe as $\{\mathrm{ni}\}$ is LB sign 34/35, and as $\{0\}$ the LB sign 43. In (Kenanidis, 1992; 2011) it has been explained that the sign 34 (together with 35, which is simply a variant of the sign 34) comes from two old Proto-Linear signs, one depicting the moon and another depicting a bead of a precious bright gem; both "moon" and "gem" were called "ni(r)" in the Cretan variety of Sumerian, and probably it was one and the same root that gave $\{\mathrm{ni}(\mathrm{r})\}$ as the name of both the moon and the gem; so the sign LB 34 (and 35) depicted the moon, but in such a way that it can also be interpreted as a round gem bead on a thread; most forms of the sign 34 and 35 are a fusion of the two images: a crescent moon and a threaded round bead, so the sign was used for the syllable \{ni\}. Traditionally, the LB syllabogram for "ni" is thought to be the LB sign 30. However, in the works mentioned (Kenanidis, 1992; 2011) it has been clarified that LB 30 was not "ni" but originally $\{\mathrm{ni}\}$ (Sumerian/ni/), so it stood for Greek/ni/, because Greek " $n$ " was usually palatalized before " $i$ " and sometimes before "e", as it is until today in some widespread Greek dialects; Greek \{ni\} with /n/ or nearly /n/ occurred only in the beginning of words or after " $\mathrm{r}$ " (and possibly after some other consonants too), such Mycenaean Greek words can be seen in Bibee \& WilsonWright (2015); the words "*34-ke-te-si" and "*34-ka-te-re" are obviously "nīkātēres" (nominative) and "nīkētērsi"

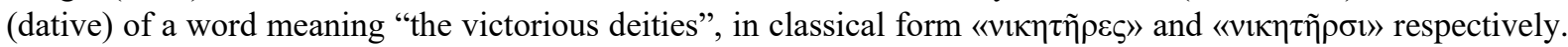
The word *34-ke-ja (a personal name) is probably an early form of classical "nikaios" (vikaĩos, "victorious") (Appendix B). 
The other words with *34 in the middle of words must have had a "r" before the "ni"; the (name proper?) "po*34-wi-do" can be read "porniwidos", possibly related to classical "pornē" ( $\pi$ ópvๆ, not in the later sense "prostitute", but in a more original sense: "seller", derived from the verb "pernēmi" / $\pi \dot{\varepsilon} \rho v \eta \mu \mathrm{u}$ "I sell"); another

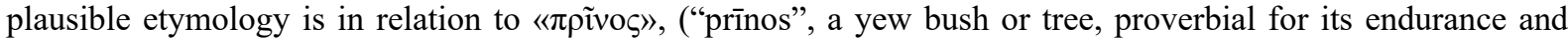
longevity); it may even be possible to connect it to Sankrit parná "feather"; otherwise, it would have to be a

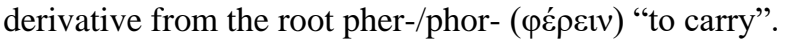

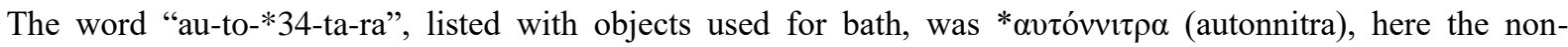
palatalized and doubled -nn- is wholesomely justified by the first element being the more original *awtod instead of classical "auto"; but also the second component "nitron" was treated similarly to a separate word by not palatalizing the ni- (as if starting a word which in fact was the second part of the compound); "nitron" was a technical word of foreign origin, referring to a chemical substance used as a detergent; so, "autonnitra" (neuter gender, plural of * "autonnitron") were some kind of objects containing the detergent in them, a formation analogous to classical "aut-andros" $=($ a ship) together with the people (andr-) in it.

Therefore, it has been a blunder for so long time to relate LB *43 ( $\{0\}$, used for Mycenaean "ai") with LB *34/35 $\{\mathrm{ni}\}$; these two have been considered related only because of the two hapax words $\{\partial \mathrm{ceu}\}$ and $\{$ niceu $\}$, but apart from these two words there is no case of a *34/35 interchangeable with *43 ("ai" / "a 3 "). And there is no reason to believe that the word "*34-ke-u" means the same as "*43-ke-u"; both were written by the same scribe, and the scribe meant them as two different words: "*43-ke-u" meant "very well", while "*34-ke-u" meant "far from; definitely not". How could it be possible for Linear B, a script that barely approximates the Greek phonology, to use two different signs for the same syllable "ai", for which not even one sign would be necessary, if "ai" were written as "a-i"!?. The fact that it was the same scribe who wrote "*43keu" and "*34keu" makes it even more impossible to think that $* 43$ and $* 34$ had the same phonetic value: of two different scribes, each of them might have preferred a different sign for the same syllable, but one and the same scribe could not have used two signs of totally different pictorial origin for the same "ai".

A similar case of different words which are suspected to be the same are the names "a $\mathrm{a}_{2}$-nu-me-no" and " $\mathrm{a}_{3}$-nu-meno", and quite rightfully Melena (Melena, 2014, p. 225) doubted about it when he wrote:

“... a $a_{2}$-nu-me-no PY Jn 389.12 (Hand 2) man's name in $-\mu \varepsilon v o \varsigma$, if a variant of a $a_{3}$-nu-me-no PyAn 261. 2 (Hand 43)..."

The two words, "a $a_{2}$-nu-me-no" and "a $a_{3}$-nu-me-no" are clearly two different words, from different roots. This is clearly understood when we know that Mycenaean "a" in "ai" was a closer vowel than a non-diphthong "a": so,

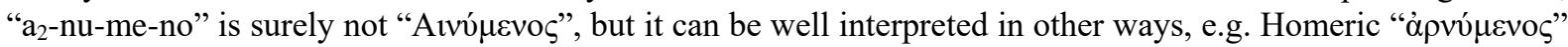
(a h- can have been lost in Homer; Homer even uses "amaksa" without the h-, which is found in classical "hamaksa"). Apvó $\mu \varepsilon v o \varsigma$ ("winning") makes perfect sense as a personal name, but if this word was with "h-" in Mycenaean Greek it is a unique case of a PIE laryngeal surviving and documented in Greek, unless classical Greek "hámaksa" shows another surviving PIE laryngeal. It is still no proof that "a" was an "e" that became "a" due to the laryngeal; it could still have been *hə- in PIE, that is the PIE "ha-", given that /a/ was the PIE short "a" (Note $5)$.

The -"eu" in the words $\{$ oceu\}, \{niceu\}, and even $\{$ opicewilijeu\} is not a meaningless coincidence: it will be shown below that it was the most usual adverbial ending in Mycenaean Greek (unlike classical Greek that mostly used -ōs for adverbs).

As noted in Bichlmeier (2014, p. 55), "o-pi-ke-wi-ri-je-u cannot be an adjective, since the suffix -êu- only forms substantives". This is a rule which might have had an exception, however \{aceu\} cannot be an adjective nor a substantive, because if it were a declinable word it would appear in the dual number as * \{acewe $\}$; in the phrase \{tilipode aceu celesijo wece\}, \{tilipode\} i.e. "tripode" is in dual number nominative, so \{aceu\} would have to be in dual number nominative too; it cannot even be in genitive as \{celesijo $\}=$ "khrēsijos", nor in any other inflected form known in Greek grammar. Therefore it has to be an indeclinable form, as also \{niceu\} and \{opicewilijeu\}; however, indeclinable forms are often "fossilized" inflected forms that were forgotten as inflected forms and

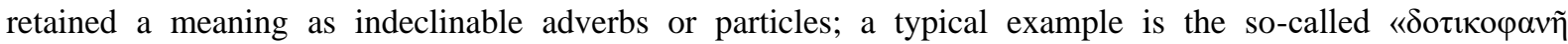
$\varepsilon \pi \iota \rho \rho \eta \tilde{\mu} \alpha \tau \alpha \gg$ (adverbs in the external form of singular number dative case nouns, especially of $1^{\text {st }}$ declension

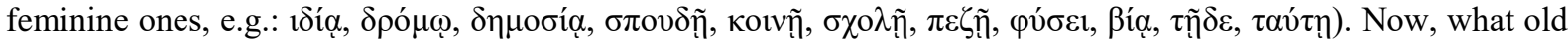
inflected form could have remained in these words ending in -ēu? The answer is given by one of the oldest IndoEuropean languages: Sanskrit, where the suffix -āu (from *-ēw / -ōw, since Sanskrit ā normally comes from older $-\overline{\mathrm{e}}$ or $-\overline{\mathrm{o}}$ ) forms the locative case of all nouns and adjectives with stems in $-\mathrm{i} / \mathrm{u}$; (then it is reasonable that nouns/adjectives with stems in -i (e.g., "Hari") may have formed originally the locative in *-êw, while those with 
stems in -u (e.g., "Viṣnu") formed the locative in *-ōw, although this is not important for the scope of this article, as $\bar{e}$ could alternate with $\bar{o}$ due to IE Ablaut). This means that in Greek too there was a singular number locative case in $-\bar{e} w$ (perhaps alternating with *-ōw), which was lost even in pre-Mycenaean times, but left, as a linguistic fossil, a suffix -ēw that formed adverbs; this suffix survived even in alphabetic Greek as «-oṽ» (-ou), forming adverbs like $\alpha \gamma \chi 0 \tilde{v}, \alpha \pi \alpha v \tau \alpha \chi 0 \tilde{v}$ (ankhou "close to", apantakhou "everywhere"); there are some pairs of adverbs like $\alpha \gamma \chi 1-\alpha \gamma \chi 0 \tilde{v}$ (ankhi - ankhou, having a form in -i and another form in -ou), which means they were originally nouns with nominative in $-\mathrm{i}$ and locative in $-\mathrm{ou}$, from older $-{ }^{*} \eta \tilde{v}(-\overline{\mathrm{e}} \mathrm{w}){ }^{*}-\overline{\mathrm{e}} \mathrm{w}$ turned to $-\mathrm{ou}$ for dissimilation to

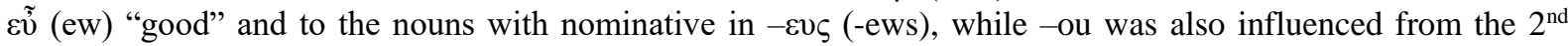
declension genitive suffix.

More traces are found in many adverbs with a locative sense, formed, even in alphabetic Greek, with a suffix $-\chi-$

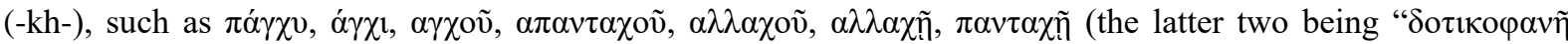

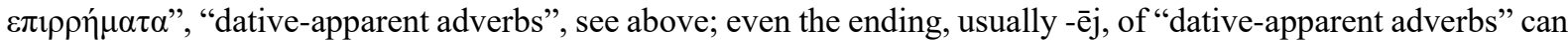
easily be explained by an older locative ending -êw; when locative case was lost in Greek, its function merged into the dative). It is the same suffix $-\chi$ - in some nouns expressing an abstract concept, as aĩ $\chi 0 \varsigma$ (aiskhos, "shame") from root "aid"-, and $1 \sigma \chi v ́ \varsigma$ (iskhus) from root "wis"- ("manly strength", usually thought to be *wih-, h being a PIE laryngeal, see Note 5). Actually, that suffix $-\chi$ - (-kh-) had a demonstrative function, so it was convenient for words indicating placement or direction, but also could be used with a psychological demonstrative (i.e. expressive) sense: aiskhos ("see, it's a shame"), iskhus ("see, he is so strong").

Back to our tablets, the words $\{$ aceu\}, \{niceu\}, \{opicewilijeu\} carry that adverbial (from older locative) suffix $\bar{e} w$, while $\{$ aceu $\}$ and $\{$ niceu $\}$ also carry the adverbial suffix $-\mathrm{kh}-(-\chi-)$; one might even argue that $\{$ aceu $\}$ is the same as alphabetic $\alpha \gamma \chi 0 \tilde{v}$ (ankhou), but this is proven impossible because there are some words starting with "aki-"

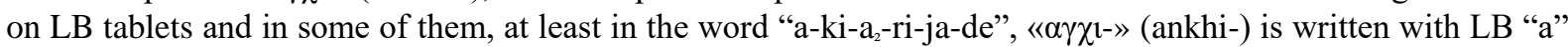
and not "a3" ("ai") which is what we have in $\{$ aceu $\}$ (Note 6).

A better conjecture for \{aceu\} ("a $a_{3}-k e-u$ ") was *ajskhēw, from the root aid- "ugliness, shame", formed like "aiskhos" (shame, ugliness), with the adverbial suffixes -kh- and -ēw which have been explained above. As in ancient times the root aid- formed the most usual terms to denote ugliness, *ajskhēw would mean "in an ugly manner", i.e. "not proudly or presentibly" (but still the two tripods are "khrēsijos wejkeh[e]", suitable for use). Although this seems grammatically correct and makes some sense, could two tripod cauldrons be "not proudly or presentibly" usable in a palace? The root aid- has a strong sense of ugliness and shame, so if those two tripods were consciously shameful to use, they would not be suitable to use in the palace (although they could be sold or recycled). And then, in all these descriptions of vessels, the imperfect tripods (and all noteworthy vessels, even much cheaper than tripods) are described one by one and their imperfection, if any, is specified in full detail. It would be too odd if two tripods were shamefully usable but their imperfections were not described for each individual tripod. On the other hand, it was natural for two tripods to be mentioned together, if they were in a very good condition, in contrast to the rest ones. So, the scribe started with the two "a $a_{3}$ keu keresijo weke" tripods which were in best condition, and then went on to describe the other tripods which had some small defects although they were usable. It is clear that "a $a_{3}$ keu" meant "very well", but the origin of the word must be also clarified: it was the

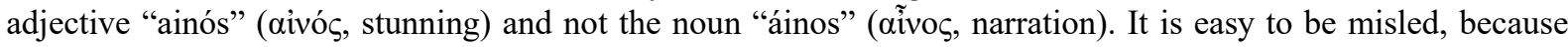
dictionaries give misleading definitions and no certain etymology for these two words: it is surely misleading to define "ainós" as "dreadful" (including Liddell \& Scott, 1940): the original meaning was not "dreadful", and if we take a close look to all occurrences of the word, it never meant "dreadful" or "horrible": it only meant "majestic

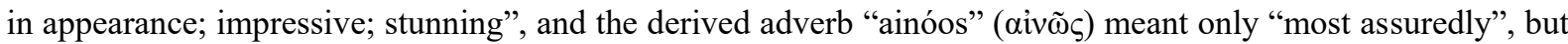
never "horribly"; such meanings as "horribl(y)" or "dreadful(ly)" were only based on context of other words with a dreadful meaning, which were only augmented by the use of aivó $\varsigma$ and aivã $\varsigma$. A good example is when the elders

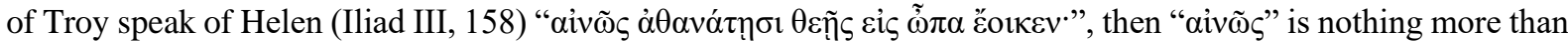
an assertion: "indeed, she looks like the immortal goddesses", although indeed the word is emphatic and carries a connotation of impressiveness, and the idea that "it is really so, because we see it". There is no word derived from

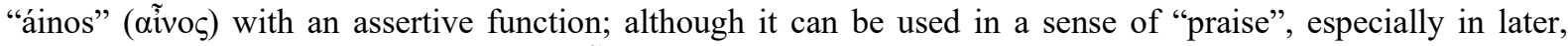
Christian literature, the original sense of aĩvo is "narration; proverb; a word inherited from the old people; word of wisdom; a word that is worth listening to". What we have here on the tablet is the Mycenaean form of aiv $\tilde{\zeta}$ (word of assertion) and not a form of aivo $\omega \varsigma$, common in alphabetic Greek, while "ajnkhēw"/ojnche:w/ was the same word formed by the old demonstrative suffix -kh- with the older adverbial ending -êw (previously explained). The same suffixes will be seen in \{niceu\}, which is the most difficult word to explain on these tablets. 
Many different thoughts were quickly rejected as irrelevant, when trying to explain \{niceu $\}$ by the root niq- "to winnow, disperse into the air"; from nīkē "victory"; from neikos "hatred"; from the root "nek" ("dead"); the only thought with some resemblance to truth, was to explain it as from "nig" ("to wash hands or feet"), a root well

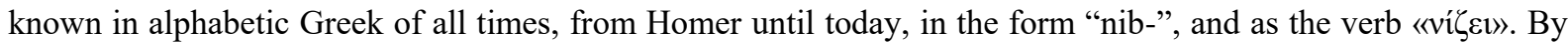
that conjecture, \{niceu\} might be read as *"nikkhēw" from *"nig-khēw", and the phrase \{celesijo weke niceu\} would be interpreted as "proper for use only as a basin for washing hands". This interpretation is clever, but quite subjective. It is not supported by any similar usage in the whole Greek language. In fact, a cauldron too old to be repaired was not proper to use as a hand-washing basin, especially in a palace. It was sooty and all over covered with the greenish patina of bronze, so it was too "aiskhros" (ugly) to be publicly used in the palace. Washing hands before meals was a public and ceremonial activity, as we see in Homer, and it would be shameful to use a rusty useless tripod for that. Also, the shape of a tripod cauldron was not fit to use as a washing basin, which should have a flat bottom, to be placed on a table. A tripod cauldron could not stand on its rounded bottom, unless on three "skéleha", legs. Besides, consider that fire was always holy with ancient Greeks and other nations; to use the cauldron for holding dirty water of washing, would be a desecrating act. In the world's literature there is no known instance of a cooking vessel that came to be used under hands being washed, even by poor people - let alone in a palace.

The only plausible explanation of \{niceu on the tablet, is to read it as "niskhēw": it is simply the well-known

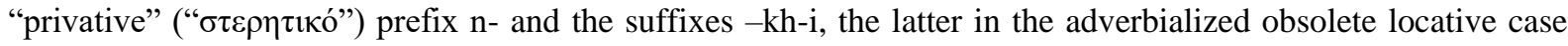
form - $\overline{\mathrm{e}} \mathrm{w}$, which is also in ainkhēw (mentioned previously), and the same fossilized suffix -ēw will be seen in \{opicewilijeu\}.

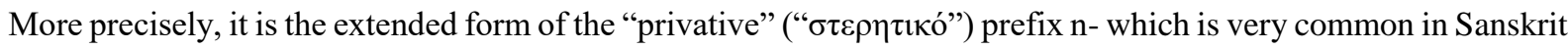
as "nis-". By the way, the compound suffix -khi (of which we have here the obsolete locative form -khēw) is also common in Sanskrit as "hi", which is both used on its own as a particle meaning "surely, of course; knowing that, because" (used like Greek "gar"), and also joint with "na" in "nahi" (meaning "of course not" etc.). In classical

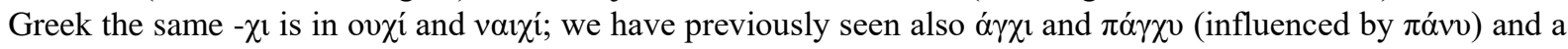
suffixed mere $-\chi$ - with a demonstrative function.

The form "niskhēw" on the tablet is an adverbialized locative corresponding to an adverbialized nominative form *niskhi which does not seem to be documented on LB tablets, but it is quite well documented in alphabetical Greek

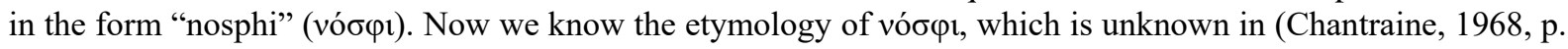
757); it comes from an original form *nəskhi, that evolved (through a slight raising of /a/ into /i//) to a vernacular form */nïskhi/, which in Mycenaean Greek became *niskhi (/nischi/; with an obsolete inflection form documented here as "niskhēw"), while in Homeric texts it reached a form "nosphi" (influenced by the locative plural suffix phi, and also influenced by the phonetic change of ("labio")velars to labials, which was regular in some era between Mycenaean and Homeric Greek; The rounding of /o/ to "o", although not regular, was not difficult, especially under influence from words with a negative meaning starting with no-, for example "nōpheles" ="useless"). "Nostos" (reaching homeland; return) can also have influenced the formation of "nosphi" as an opposite concept word. Other unknown reasons could have accounted for */nəsk ${ }^{\mathrm{h}} \mathrm{i} /$ to $/$ nosp $^{\mathrm{h}} \mathrm{i} /$ such as an unknown

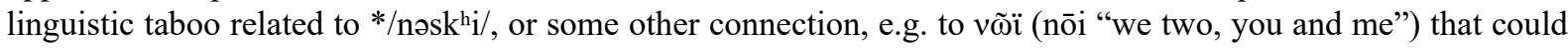
imply "without the others", for which meaning /nosp $\mathrm{h}^{\mathrm{h}} /$ was often used.

Another word importantly showing that suffix *-khi with an extended parallel form *-khēw is the old adverb, later preposition and conjunction "mesphi / mespha": both forms "mesphi" and "mespha", as also an usuffixed form "mes" have been attested, and unfortunately these have not been connected to "nosphi" in (Chantraine, 1968, p. 689). The form "mespha" is due to an obsolete $* / \mathrm{mesk}^{\mathrm{h}} \mathrm{e}: \mathrm{w} /$ (if not $* / \mathrm{m} \mathrm{sk}^{\mathrm{h}} \mathrm{e}: \mathrm{w} /$ ) after influence by many prepositions (and even adverbs) ending in -a.

So, with \{niceu\} being "niskhēw", a form of the classical "nosphi" meaning "far from; separately; without; missing", the phrase \{celesijo weke niceu\} is to be read "khrēsijos wejkēs niskhēw" = "for use suitable not any more" = not anymore suitable for use (which indirectly implies that the tripod cauldron had been repaired repeatedly in the past but it would be meaningless to try and repair it any further).

\subsection{Etymological Analysis of "opikewirijeu" / \{opicewilijeu\}}

The other difficult word on these texts is \{opicewilijeu\}; -eu is the same fossilized locative case suffix we saw before (Note 7).

The component opi- is the well-known Mycenaean form of classical epi-. Considering that opi- is classical epi-, \{opicewilijeu\} / "opikewirijeu" is instantly reminiscent of the words episkeue ("repair") and episkeuaz- (to repair), which are very ancient words, and exist until today in Greek. Some inscriptions in the Cypriot Greek syllabary 


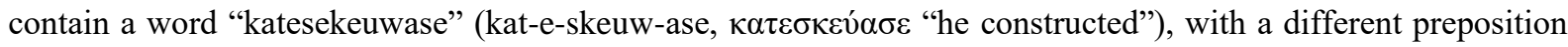
but the same root $\sigma \kappa \varepsilon v$ (skew-). Episkeuē ("repair") makes the best sense in this context: "a tripod cauldron that will be proper to use when it is repaired".

The only remaining question about \{opicewilijeu\} is its exact grammatical form; it seems to be "opiskewirjēw" or "opiskewrjēw", but then what is after the root skew- and before the suffix -ēw? To the best of my understanding, this form on the tablet can be explained only by a small scribal error: the scribe wrote "opikewirijeu" instead of the correct "opikewitirijeu"; it was much easier to make the mistake than to write the word correctly, for the following reasons:

- the word was very long;

- the omitted sign "ti" was similar in shape to "wi": both "wi" and "ti" resemble a $\Lambda$ with some additional little lines inside it;

- the omitted "ti" has the same vowel as the previous and the following sign: -"wi(ti)ri"-;

- the "ti" was only for the " $\mathrm{t}$ ", not for a whole syllable; the syllable was rendered by the sign "ri", so the scribe felt that every syllable was written, thus nothing was felt to be missing;

- "ri" sounds very similar to "tri", so, by writing "ri", the scribe thought that s/he wrote "tri".

In the corrected form "opiskewitrijēw", the suffix root-tr- is well-known in Greek and in PIE for two functions: for marking "nomina agentis" (nominative -tēr /-tōr for the male and -tri[j]a for the female) and for "nomina instrumenti" (usually neuter: -tron); these two functions, ("nomina agentis" and "nomina instrumenti") are originally one: they come from one and the same concept, "the doer", person or thing doing something. So, "opiskewitrjēw" used the "doer" suffix -tr- and the adverbialized old locative ending "-êw". The -i- (turning to j or ij) before "-êw" is explained by the most ancient adverbial suffix -i, which is e.g. in $\alpha \mu \imath \sigma \theta i$, $\alpha v \theta \omega \rho \varepsilon i$ etc, and in many cases it is expanded into - $\tau \dot{i}\left(\alpha \mu \alpha \chi \eta \tau_{i}, \alpha \kappa o v i \tau i ́, \alpha \sigma \kappa \alpha \rho \delta \alpha \mu \nu \kappa \tau i ́, \mu \varepsilon \gamma \alpha \lambda \omega \sigma \tau i\right)$ for indicating manner, and in

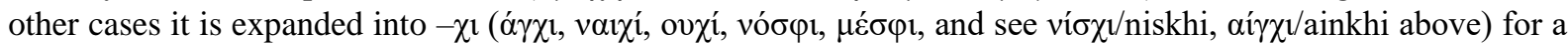
demonstrative, often locative, function. As explained previously, the adverbs in -i were for some time considered adjectives in nominative, of which the corresponding locative ending is "-ēw"; so, the form "opiskewitrijēw" shows that there was in use also an adverb *opiskewitrí meaning "by repair", and that *opiskewitrí was the more common form, but as the scribe had in mind other adverbs ending in "-ēw" (ainkhēw, niskhēw) referring to the condition of tripod cauldrons, and possibly also had in mind the adverb "ew" ( $\varepsilon \tilde{\tilde{v}}$, meaning "well, in good condition", contrasted to those not so perfect cauldrons), s/he preferred to use the form ending in "-ēw", still influenced by *opiskewitrí, so made it "opiskewitrijēw".

It is highly preferable to reconstruct it as "opiskewitrijēw", in which case the "i" after the "w" is simply epenthetic to ease the pronunciation. A reading "opiskewtrijêw" is also possible, without any difference of meaning.

We should consider also that there must have been an undocumented word *opiskewitèr (masculine) and *opiskewitrija (feminine) corresponding to the documented (Ventris \& Chadwick, 1953) "aketirija" = akestrijaj, which made for the adverb *opiskewitrí (meaning "by means of the repairer"). Of course, *opiskewitēr and *opiskewitrija meant "a repairer", so the word is indeed a synonym of akestrija, only that the akestrija mended by using thread and needles, while the *opiskewiter and *opiskewitrija repaired by other means.

\section{Results}

In table 1 we can see that not all sketches of tripods are the same; the photographs (above) are more reliable than the modern copies (below), still the modern copies are useful to show the size of each sketch in relation to the space of each line; so we can see that the shape and size of the sketches are connected to the quality and usability of the tripod cauldrons.

The examination (presented above, in the section 2) of the texts about tripods on these two clay tablets results in the reading and translation provided in the table 1 . 
Table 1. The sketches and descriptions for each tripod cauldron

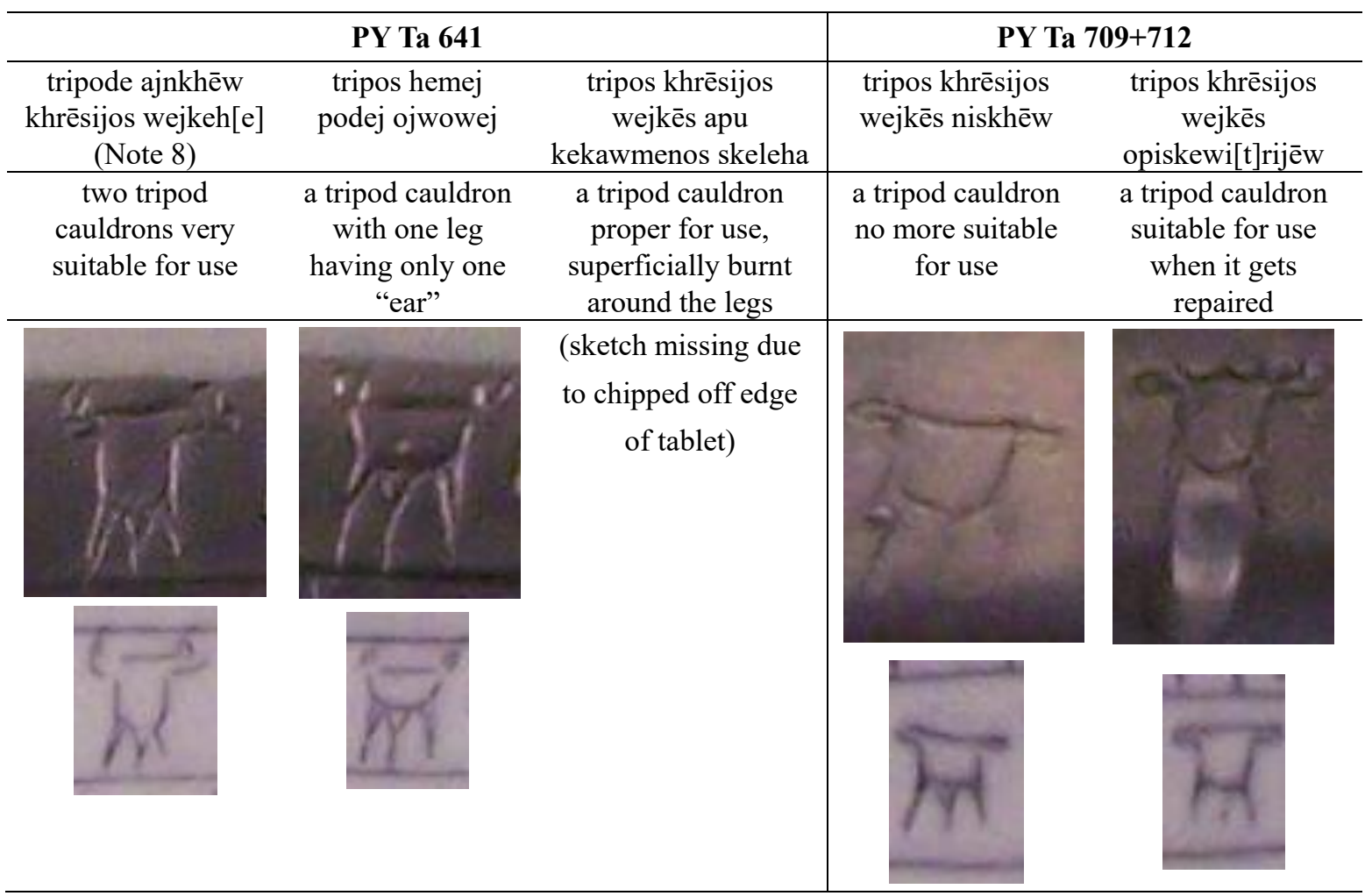

\section{Discussion \& Conclusion}

After the reading and interpretation (section 3 , table 1) we can notice that the scribe made the sketches according to the real shape and condition of the tripods, while psychologically connecting quality to size: the better the condition of the tripods, the bigger s/he made the sketch (table 1). The best condition tripod cauldrons (left column) were drawn with a big body, while in the second column from the left, the cauldron with only one "ear" (in this case "ear" meaning a lesser handle) on a leg was drawn with the legs shown big, especially the middle leg. In the 4th column from left, the worst preserved cauldron is drawn as smallest of all, with the brim slanting to the right and visibly sagging; while the better cauldrons (left two columns) show their "ears" (i.e. main handles) erect, the worse ones (right two columns) show their "ears" horizontal; and it is only the last (on the right) tripod cauldron that was drawn with a wavy brim, to indicate that the brim can be straightened by hammering (repair).

Comparing the two tablets, we also notice another typical process followed by the professional scribe; both tablets list other things together with the tripod cauldrons: the tablet on the left lists various kinds of containers, while the tablet on the right lists things useful for cooking and serving food, such as fire starter devices, grillers, ladles and bowls; but when the tripods recorded are in more or less good condition, they are mentioned first, before the other things, as seen on the "left" tablet; on the "right" tablet, where the tripods recorded are in a more or less bad condition, they are mentioned last, after all the other items.

So, once again the sketches helped to confirm the correct reading of the LB texts; this time being texts describing the tripods in terms of their usability.

\section{References}

Bibee, W. E., \& Wilson-Wright, A. M. (2015). A Laryngeal in Linear B: Evidence from Ugaritic and Egyptian (The University of Texas at Austin). 14th Mycenological Colloquium, Copenhagen, Denmark, September 5, 2015.

Bichlmeier, H. (2014). Studien zur Verwendung der Lokalpartikeln im Mykenischen. Wiesbaden: Dr. Ludwig Reichert Verlag, p. 152. Retrieved from http://www.bmcreview.org/2014/12/20141219.html

Chadwick, J. (1955). A Critical Appendix to the Pylos Tablets. Cambridge: Museum of Classical Archaeology, pp. 138-148. 
EvBoKHY1YD4YQFggzMAQ\&url=http\%3A\%2F\%2Frevistas.usal.es\%2Findex.php\%2F05443733\%2Farticle\%2Fdownload\%2F2836\%2F2875\&usg=AFQjCNG08RRHADdGXllwJWRIVvQTMEK6r A\&sig2=A86ZLrqy_8KcvN1LCXsfRg

Chantraine, P. (1968). Dictionnaire Étymologique de la Langue Grecque. Paris: Éditions Klincksieck.

Diccionario, M. (DMic.). Biblioteca Virtual Miguel de Cervantes de la Universidad de Alicante. Retrieved from http://www.cervantesvirtual.com/bib/portal/diccionariomicenico/contenido/wo.html

Dickinson, O. (1994). The Aegean Bronze Age. Cambridge, UK: Cambridge University Press.

Janke, R. V. (2014). An archaeologist's translation of Pylos Tablet TA 641-1952 (Ventris), with an introduction to supersyllabograms in the vessels \& pottery sector in Mycenaean Linear B. Archaeology and Science, 10, 133161. Retrieved from https://www.academia.edu/23643380/Archaeology_and_Science_Vol__10_2014_An_Archaeologists_Transl ation_of_Pylos_Tablet_641-1952._pp._133-161

Kenanidis, I. (1992). Eteokreetes Megaleetores. Athens: National Library of Greece (in Greek).

Kenanidis, I. (2011). Cwepeker. In I. Kenanidis (ed.), Historical and Linguistic Studies (pp. 26-191). Kavala, Greece: Deposited to the notary E.P. Lazidou in 2013 (in Greek). Retrieved from https://www.academia.edu/3436810/EVERYTHING_of_the_Minoan_Civilization

Kenanidis, I. K., \& Papakitsos, E. C. (2015). A Comparative Linguistic Study about the Sumerian Influence on the Creation of the Aegean Scripts. Scholars Journal of Arts, Humanities and Social Sciences, 3(1E), 332-346. Retrieved from http://saspjournals.com/sjahss-31/

Kenanidis, I. K., \& Papakitsos, E. C. (2018). Cretan Protolinear Script: The Sixth-Vowel Set of Syllabograms. International Linguistics Research, 1(1), 32-48. https://doi.org/10.30560/ilr.v1n1p32

Liddell, H. G., \& Scott R. (1940). A Greek-English Lexicon (Revised and augmented throughout by Sir Henry Stuart Jones with the assistance of Roderick McKenzie). Oxford: Clarendon Press.

Melena, J. (2014). Filling Gaps in the Linear B Additional Syllabary: The Case of Syllabogram *34. In A. Martínez Fernández, B. Ortega Villaro, H. Velasco López \& H. Zamora Salamanca (eds.), 'ł $\gamma \alpha \lambda \mu \alpha$. Homenaje a Manuel García Teijeiro (pp. 207-226). Valladolid: Secretariado de Publicaciones e Intercambio Editorial Universidad de Valladolid.

Raymoure, K., Minoan, L. A., \& Mycenaean Linear B. Retrieved from $\mathrm{http} / / /$ minoan.deaditerranean.com/resources/linear-b-sign-groups/o/o-pi/o-pi-ke-wi-ri-je-u/

Palaeolexicon. (N/A). Word study tool for ancient languages. Retrieved from http://www.palaeolexicon.com/

Papakitsos, E. C., \& Kenanidis, I. K. (2015). Additional Palaeographic Evidence for the Relationship of the Aegean Scripts to the Sumerian Pictography. Scholars Journal of Arts, Humanities and Social Sciences, 3(3C), 734737. Retrieved from http://saspjournals.com/sjahss-33/

Ruijgh, C. J. (1962). Tabellae Mycenenses Selectae (76 pages). Leiden: E.J. Brill.

Ventris, M., \& Chadwick, J. (1953). Documents in Mycenaean Greek. Cambridge: Cambridge University Press. WordWeb dictionary. (N/A). Retrieved from http://wordweb.info/

\section{Notes}

Note 1 . In the traditional transliteration of PIE, a ' mark on or after a $\mathrm{k} / \mathrm{g}$ indicates that it is palatal.

Note 2. Judging at least from the handwritings and the tidiness of Linear B scribes, I consider that most if not all of them must have been women rather than men.

Note 3. See verb form in:

http://www.perseus.tufts.edu/hopper/morph?l=w\%29\%2Fnato\&la=greek\&can=w\%29\%2Fnato0\&prior=m'\&d=P erseus:text:1999.01.0133:book=17:card=25\&i=1\#lexicon.

Note 4. A supposed compound from *"krēsijo-" and "-werg'ēe" meaning "wrought" from the root "werg'".

Note 5. Even so, it is a harmful trend to "discover" laryngeals everywhere and explain everything by laryngeals in the old Indo-European languages. Most scholars nowadays think that every "a", many "o"s and every word initial vowel in ancient IE languages are due to laryngeals; I suggest that more proof is needed to establish a laryngeal. 
Note 6. This must be «A $\gamma \chi 1 \alpha \lambda \iota \alpha ́ v \delta \varepsilon »$ (Ankhi-halijan-de) a place name meaning "near the sea" with allative suffix

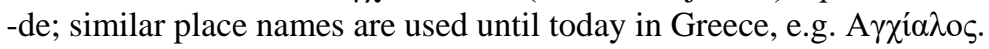

Note 7. We cannot exclude a chance that some popular false etymology might have connected that suffix -eu to Mycenaean "eu" (Classical Eṽ "good, well"), which could make sense in this context; accordingly also ainkhēw might have had a connotation of good appearance, and niskēw a connotation of "no good". Such a popular false etymology might have applied to "opiskewitrijēw" as "good after a repair".

Note 8 . The scribe made a slight mistake here: s/he ought to write "ke-re-si-jo we-ke-e" but wrote only "ke-re-sijo we-ke"; a similar slight mistake is in the second line of the same tablet, s/he wrote "di-pa me-zo-e qe-to-ro-we" instead of the correct "di-pa me-zo qe-to-ro-we". I do not dare to say that s/he made those small mistakes because s/he did not know Greek grammar perfectly, (her)self being a Minoan Sumerian, according to the theory presented in Kenanidis (1992; 2011), Kenanidis \& Papakitsos (2015) and Papakitsos \& Kenanidis (2015). In fact the scribes spoke Greek really better than Minoan Sumerian, but it was easy to make such small mistakes, as "ke-re-si-jo weke" was a habitual expression (written four times by the same scribe on these two tablets), and then, when writing the first "me-zo-e" the scribe was thinking of the next words to write: "di-pa-e me-zo-e ti-ri-o-we-e".

\section{Appendix A}

\section{Similar modern use of the verb "apokaiō"}

Even today there is a use of the verb «aлокаí $\omega »$ :

(http://www.ethnos.gr/koinonia/arthro/kyprioi_dasokomantos_bazoun_foties_gia_na_sbisoun_tis_floges129077/ retrieved in May 2016) for a technique of burning the trees around a fire so as to prevent it from spreading. It is an article from a Greek newspaper with a heading "Cypriot forest-commandos set fires in order to put out the flames"; their method is described by a traditional use of the verb "apokaiō".

\section{Appendix B}

\section{Proof about the nature of Mycenaean "a"}

Even if *34 were not $\{$ ni $\}$, “*34-ke-te-si” and "**34-ka-te-re" are necessarily different forms (cases) of the same noun, and note that one scribe uses "ka" where the other uses "ke" in the same word; this is the phenomenon generalized later in the Ionian dialect, where the long "a", originally central /ä:/, was made slightly more front and

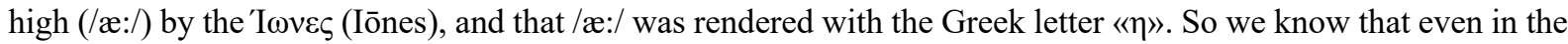
Mycenaean Greek language long "a" was fronted as /a:/, very near to /æ:/. This means that "a" was originally a central vowel, given that it could easily be fronted. It was not originally a front vowel, because the fronting Ionian dialects were clearly differentiated from all the other Greek dialects, which did not front the "a".

\section{Copyrights}

Copyright for this article is retained by the author(s), with first publication rights granted to the journal.

This is an open-access article distributed under the terms and conditions of the Creative Commons Attribution license (http://creativecommons.org/licenses/by/4.0/). 